\title{
HEAT FLUXES AND RIVER ENERGY BUDGET ON THE EXAMPLE OF LOWLAND ŚWIDER RIVER
}

\author{
MAKSYM ŁASZEWSKI \\ Institute of Physical Geography, University of Warsaw, Poland
}

Manuscript received: 21 October, 2014

Revised version: 31 December, 2014

ŁASZEWSKI M., 2015. Heat fluxes and river energy budget on the example of lowland Świder River. Quaestiones Geographicae 34(1), Bogucki Wydawnictwo Naukowe, Poznań, pp. 65-74, 5 tables, 5 figs. DOI 10.1515/quageo-2015-0006, ISSN 0137-477X.

\begin{abstract}
The paper present the energy budget of the downstream part of lowland Świder River, right tributary of the Vistula River in Mazovian Lowland, Poland. Heat fluxes were calculated on the example of four days, representing different meteorological and vegetative conditions. Results confirmed the dominant role of radiation, which accounted for an average of $90.7 \%$ and $79.7 \%$ gains and losses of thermal energy. Participation of non-radiative components proved to be far less crucial; the average contribution of condensation, sensible heat transfer, bed conduction and friction in energy gains accounted respectively to $0.0 \%, 0.6 \%, 2.9 \%$ and $5.9 \%$, while the average contribution of evaporation, sensible heat transfer and bed conduction in energy losses reached respectively $4.5 \%, 1.1 \%$ and $14.6 \%$. The results showed significant effect of riparian vegetation and cloud cover on river heat fluxes.
\end{abstract}

Key words: heat fluxes, river energy budget, water temperature, the Świder River, Poland

Address of the author: Maksym Łaszewski, Institute of Physical Geography, University of Warsaw, Warsaw, Poland, e-mail:m.laszewski@uw.edu.pl

\section{Introduction}

Temperature plays an essential role in lotic environment, influencing physical, chemical and biological water properties (Allan and Castillo 2007). In consequence stream temperature has great ecological significance, as well as measurable economic importance, particularly in the context of fisheries (Armour 1991, Malcolm et al. 2008). Therefore, good understanding and prediction of stream water temperature seems to be an inseparable part of appropriate water resources management. For this purposes there were carried out detailed studies on river energy budgets in UK and U.S. in different spatial and time scales (Webb and Zhang 1997, 1999, Evans et al. 1998, Hebert et al. 2011, Benyahya et al. 2012, Xin and
Kinouchi 2013, Garner et al. 2014). Similar studies on Polish rivers do not actually exist, generally due to the lack of precise microclimatic measurement data.

To fill the gap, the main objective of this paper is to establish simple diurnal energy budget of the lowland Świder River, based on meteorological data collected in field experiment. Heat fluxes were calculated on the example of four days, representing different meteorological and vegetative conditions. This allowed to exhibit significant daily patterns of the energy budget components and present preliminary conclusions about the influence of environmental parameters on water temperature. 


\section{Study area}

The study was carried out in the downstream part of the Świder River, which is a 99-kilometer-long tributary of the Vistula River in the Mazovian Lowland region in central Poland (Fig. 1). Świder drains an area of approximately 1160.70 $\mathrm{km}^{2}$ and its average flow at the Otwock-Wólka Mlądzka gauging station in the years 1960-1999 was $4.35 \mathrm{~m}^{3} \cdot \mathrm{s}^{-1}$. The river catchment is located in a temperate climate with an average annual air temperature of $8^{\circ} \mathrm{C}$ and an average annual precipitation of approximately $550-600 \mathrm{~mm}$. The site of the study, located near Otwock-Wólka Mlądz$\mathrm{ka}$, is characterized by a relatively straight channel with east-west orientation, an average depth of about $50-70 \mathrm{~cm}$, and an average width of 12 $12.5 \mathrm{~m}$. The streambed is built mainly of medium and coarse sand, while the banks are covered with riparian vegetation, which is dominated by trees, such as willows, alders, and poplars. The site was chosen mainly due to its relative homogeneity (in the context of bed sediments, shading, and width/depth ratio), as well as the proximity of the Otwock-Wólka Mlądzka gauging station; it can be considered as a typical for small lowland Polish river.

\section{Methods}

Hydrometeorological data was obtained from microclimatic field measurements conducted with the use of an A-STER weather station and HOBO data loggers (Table 1). Pyranometer, air temperature/relative humidity, and wind speed sensors were temporarily installed two meters above the water surface on the north bank of the river. Atmospheric pressure was obtained from the Warszawa-Okęcie airport meteorological station, which is located about $27 \mathrm{~km}$ from the studied area (it was possible to make this assumption due to the relatively small spatial variation

Table 1. Detailed sensors specifications

\begin{tabular}{|l|l|l|}
\hline $\begin{array}{c}\text { Sensor/data } \\
\text { logger type }\end{array}$ & \multicolumn{1}{|c|}{$\begin{array}{c}\text { Measured } \\
\text { parameter }\end{array}$} & \multicolumn{1}{|c|}{ Precision } \\
\hline CMP3 & Solar radiation & $\pm 20 \mathrm{~W} \cdot \mathrm{m}^{-2}$ \\
\hline \multirow{2}{*}{ HMP45D } & Air temperature & $0.2^{\circ} \mathrm{C}$ \\
\cline { 2 - 3 } & Relative humidity & $\begin{array}{l}2 \% \text { in range } 0-90 \% \\
3 \% \text { in range } 90-100 \%\end{array}$ \\
\hline W-043 & Wind speed & $1 \mathrm{~m} \cdot \mathrm{s}^{-1}$ \\
\hline U22-001 & Water temperature & $0.2^{\circ} \mathrm{C}$ \\
\hline UA-008 & $\begin{array}{l}\text { Streambed temper- } \\
\text { ature }\end{array}$ & $0.4^{\circ} \mathrm{C}$ \\
\hline
\end{tabular}

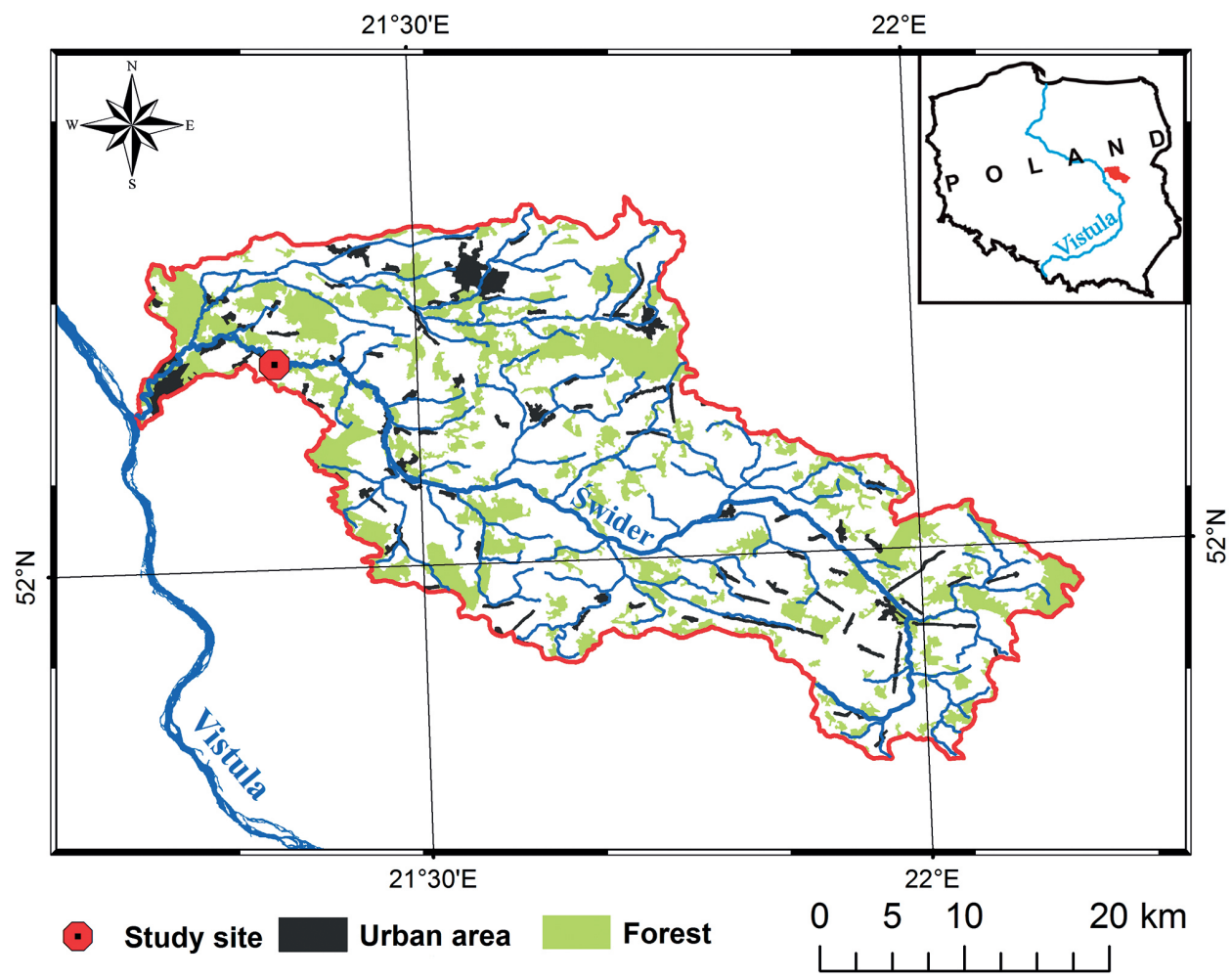

Fig. 1. River catchment and location of study site 
of atmospheric pressure and similar ASL mean height of Warsaw-Okęcie meteorological station and the site of the study). Water temperature was measured by HOBO data logger, placed in special protection housing. Streambed temperature was measured at the depth of $25 \mathrm{~cm}$ under the top of the bed by HOBO data logger, placed inside perforated PVC pipe at the middle part of the channel bed in shaded site. Both data loggers and sensors were synchronized; the interval between measurements was 10 minutes.

Heat flux on the air-water and streambed-water interfaces occurs as a result of physical processes, mainly through radiation, evaporation, conduction and advection (Theurer et al. 1984). Therefore, the energy budget of short river reach without tributaries, which expresses total heat flux, was approximated by the following equation:

$$
Q_{t} \approx \pm Q_{r} \pm Q_{e} \pm Q_{s b} \pm Q_{b c}+Q_{f c}
$$

where $Q_{t}$ - total net heat energy exchange, $Q_{r}$ heat flux due to radiation, $Q_{e}$ - heat flux due to evaporation/condensation, $Q_{s b}$ - heat flux due to sensible heat transfer between air and water, $Q_{b c}$ heat flux due to streambed conduction, $Q_{f c}$ - heat flux due to fluid friction.

Radiation component $Q_{r}$ can be considered as sum of particular radiation fluxes: $Q_{s}$ (short-wave solar radiation), $Q_{l a}$ (long-wave atmospheric radiation), $Q_{v v}$ (long-wave riparian vegetation radiation) and finally $Q_{l w}$ (long-wave water back radiation).

Solar radiation was measured directly by pyranometer. Energy gain due to solar radiation $Q_{s}$ after taking into account reflectivity of the water can be described by the equation:

$$
Q_{s}=\left(1-C_{s}\right) R
$$

where: $R$ - measured solar radiation $\left[\mathrm{W} \cdot \mathrm{m}^{-2}\right]$, $\mathrm{C}_{\mathrm{s}}$ - short-wave radiation reflectivity coefficient [0.03].

Long-wave atmospheric radiation $Q_{l a}$ was calculated using the equation given by Hebert et al. (2011) and Benyahya et al. (2012), which is directly based on Stefan-Boltzmann law:

$$
Q_{l a}=\left(1-C_{l}\right)(1-F C) \mathrm{e}_{a} \sigma\left(T_{a}+273.16\right)^{4}
$$

where: $C_{1}$ - long-wave radiation reflectivity coefficient [0.03], $\sigma$ - Stefan-Boltzmann constant $\left[5.67 \cdot 10^{-8} \mathrm{~W} \cdot \mathrm{m}^{-2} \cdot \mathrm{K}^{-4}\right], \varepsilon_{a}-$ atmospheric emissivity $[-], F C$ - forest cover factor [-], $T_{a}-$ air temperature $\left[{ }^{\circ} \mathrm{C}\right]$.

Atmospheric emissivity $\varepsilon_{a}$ was estimated by equation given by Morin and Couillard (1990):

$$
\varepsilon_{a}=\left(0.74+0.0065 e_{a}\right)\left(1+0.17 C C^{2}\right)
$$

where: $e_{a}$ - actual vapour pressure at air temperature [mbar], CC - cloud cover factor [-].

Actual vapour pressure at air temperature was determined on the basis of the relationship between relative humidity and saturated vapour pressure (Deas and Lowney 2000):

$$
e_{a}=\frac{R H}{100} E_{a}
$$

where: $e_{a}$ - actual vapour pressure at air temperature [mbar], $R H$ - relative humidity [\%], $E_{a}$ - saturation vapour pressure at air temperature [mbar].

Saturation vapour pressure at air temperature was estimated on the base of Magnus-Tetens empirical equation (Buck 1981). Coefficients were adopted from Alduchov and Eskridge (1996):

$$
E_{a}=6.1094 \exp \frac{\left(17.625 T_{a}\right)}{\left(243.04+T_{a}\right)}
$$

where: $E_{a}$ - saturation vapour pressure at air temperature $[\mathrm{mbar}], \mathrm{T}_{a}$ - air temperature $\left[{ }^{\circ} \mathrm{C}\right]$.

The above function well approximates the relationship in the temperature range from -40 to $50^{\circ} \mathrm{C}$ (Alduchov and Eskridge 1996) so its use is therefore justifiable.

Long-wave radiation emitted from the riparian vegetation $Q_{l v}$ was expressed by the equation given by Theurer et al. (1984). For simplicity it is assumed that the riparian vegetation temperature corresponds to the ambient air temperature:

$$
Q_{l v}=\left(1-C_{l}\right) \varepsilon_{f} \sigma F C\left(T_{a}+273.16\right)^{4}
$$

where: $\varepsilon_{f}$ - emissivity of riparian vegetation [0.97], $C_{r} \sigma, F C i T_{a}$ - same as in equation (3).

Long-wave water back radiation $Q_{k w}$ emitted from the water surface was described by the equation given by Deas and Lowney (2000):

$$
Q_{l w}=-\varepsilon_{w} \sigma\left(T_{w}+273.16\right)^{4}
$$


where: $\varepsilon_{w}$ - water emissivity [0.97], $\sigma$ - same as in equation (3), $T_{w}$ - water temperature $\left[{ }^{\circ} \mathrm{C}\right]$.

Heat flux due to evaporation/condensation processes $Q_{e}$ was expressed by the equation given by Westhoff et al. (2007):

$$
Q_{e}=-E_{v} L \rho
$$

where: $E_{v}$ - rate of evaporation/condensation $\left[\mathrm{mm} / \mathrm{d}^{-1}\right], L-$ latent heat of vaporization $\left[\mathrm{J} \cdot \mathrm{g}^{-1}\right]$, $\rho$ - density of the water $\left[\mathrm{g} \cdot \mathrm{cm}^{-3}\right]$.

Latent heat of vaporization $L$ was calculated from the relationship with air temperature as follows (Webb and Zhang 1999):

$$
L=2454.9-2.366 T_{a}
$$

where: $T_{a}$ - ambient air temperature $\left[{ }^{\circ} \mathrm{C}\right]$.

Rate of evaporation/condensation process was estimated on the base of aerodynamic Dalton formula, where intensity of evaporation is a function of wind speed and vapor pressure (Boyd and Kasper 2003). For the study it was used equation given by Webb and Zhang $(1997,1999)$ :

$$
E_{v}=0.165\left(0.8+\frac{U}{100}\right)\left(E_{w}-e_{a}\right)
$$

where: $E_{v}$ - rate of evaporation/condensation $\left[\mathrm{mm} \mathrm{d}^{-1}\right], U$ - wind speed measured $2 \mathrm{~m}$ above water surface $\left[\mathrm{km} \mathrm{d}^{-1}\right], E_{w}$ - saturation vapour pressure at the water temperature [mbar], $e_{a}-$ actual vapour pressure at air temperature [mbar].

The intensity of sensible heat transfer process was determined by estimating the Bowen ratio $B_{r}$, given by the following equation (Bowen 1926):

$$
B_{r}=\frac{Q_{s b}}{Q_{e}}
$$

where: $Q_{s b}$ - sensible heat exchange $\left[\mathrm{W} \cdot \mathrm{m}^{-2}\right], Q_{e}-$ latent heat $\left[\mathrm{W} \cdot \mathrm{m}^{-2}\right]$.

Bowen ratio $B_{r}$ was calculated as:

$$
B_{r}=\frac{0.61}{1000} \frac{P\left(T_{w}-T_{a}\right)}{\left(E_{w}-e_{a}\right)}
$$

where: $P$ - atmospheric pressure [mbar], $T_{a}$ - air temperature $\left[{ }^{\circ} \mathrm{C}\right], T_{w}$ - water temperature $\left[{ }^{\circ} \mathrm{C}\right]$, $E_{w^{\prime}} e_{a}$-same as in equation (11).
Amount of heat exchanged in bed conduction process $Q_{b c}$ was expressed by equation, based on Theurer et al. (1984):

$$
Q_{b c}=-k \Delta T
$$

where: $k$ - thermal conductivity of bed sediments $\left[\mathrm{W} \cdot \mathrm{m}^{-1} \cdot{ }^{\circ} \mathrm{C}^{-1}\right], \Delta \mathrm{T}$ - vertical streambed temperature gradient $\left[{ }^{\circ} \mathrm{C} \cdot \mathrm{m}^{-1}\right]$.

Energy gained from the process of fluid friction $Q_{f c}$ was determined by the following equation, justified on basic physics, given by Theurer et al. (1984):

$$
Q_{f c}=9805 \frac{D}{W} S
$$

where: $D$ - flow rate $\left[\mathrm{m}^{3} \cdot \mathrm{s}^{-1}\right], W$ - average river width $[\mathrm{m}], S$ - stream gradient.

Energy budget calculated in this study has been simplified - advective components, associated with groundwater inflows and precipitation, were neglected. Forest cover factor (FC) was defined as a part of the water surface shaded by riparian vegetation from the incident radiation from the atmosphere ( 0 - lack of shading, 1 - complete shading). It was assumed that this factor did not alter during each study day. Cloud cover factor (CC) was assessed as the degree of cloudiness of the sky seen from the place of meteorological measurements, and its value was verified every 10 minutes ( 0 - cloudless, 1 - overcast). There was also assumed isotropy of the coefficient of thermal conductivity of sediments, although in fact it shows variation both in time and space (Hondzo and Stefan 1994). The coefficient of thermal conductivity was taken from the literature as $2.2 \mathrm{~W} \cdot \mathrm{m}^{-1} \cdot{ }^{\circ} \mathrm{C}^{-1}$ because this value is suggested for sandy, saturated bed sediments (Deas and Lowney 2000), dominant in the case of Świder River. Flow rate was obtained from hydrometric gauging station Otwock-Wólka Mlądzka, which is located $3 \mathrm{~km}$ downstream from the study site. This approximation was possible in the case of absence of tributaries between the two profiles. It was also assumed a steady stream gradient from the spring to the mouth, which made it possible to use the mean value of $1.2 \mathrm{~m} \mathrm{~km}^{-1}$.

Measurement days were selected to show diurnal heat flux patterns in different meteorological and vegetative conditions; the key determinants were in fact the sun angle, air temperature values, 
and the degree of shading by riparian vegetation. Regardless of the season, the measurement days were characterized by a relatively stable flow rate. Hydrometeorological data was collected from midnight to midnight (00:00 to 00:00).

\section{Results}

\section{Hydrometeorological background}

Measurement days distinguished themselves in diverse meteorological and vegetative conditions (Table 2). 4 July can be considered as typical for summer period, with high sunbeams angle, cloudless sky (CC: 0 ), and riparian vegetation in maximum extent of development. On $30^{\text {th }}$ of September meteorological conditions were specific for autumn, with morning ground frost, low flow rate, cloudy sky (CC: $0-0.7$ ), and high relative humidity of the air. In turn, conditions on $18^{\text {th }}$ of March were characteristic for early spring: low sunbeams angle, overcast sky (CC: 0.9-1), and high flow rate. Total lack of leaves on the riparian trees during this day resulted in the lowest forest cover factor. Finally, 13 May can be considered as good representation of late spring period. There were two intense rainfall events, combined with thunderstorms. In consequence, diurnal variability of measured parameters - solar radiation, air temperature, and relative humidity - was very dynamic, as well as cloud cover (CC: 0-1).

\section{Heat fluxes and energy budget}

Diurnal patterns of heat fluxes were driven mainly by meteorological conditions so energy gained and lost by water column depended on the season and the time of the day. Absolute average gains and losses of the energy for all four days are presented in Table 3, while average percentage contributions of gains and losses of the energy are shown in Table 4 . The sign convention used is positive $(+)$ for heat gained by the water column and negative (-) for heat lost from the water column.

Major components in energy budget of the downstream Świder River were radiative heat fluxes. On average, contribution of radiative heat flux in heat gains ranged between $83 \%$ and $96.5 \%$ while in heat losses between $68.5 \%$ and $95.5 \%$. Higher participation of radiative heat flux was observed in May and July, when higher air temperature and higher sunbeams angle were observed. Total radiation balance, due to the diurnal cycle of solar radiation, was both negative and positive. Negative values of total radiation balance were observed during the night, in turn positive values were noted from 07:00-09:00 to 17:00-19:00 (Fig. 2 and 3). Long-wave radiation balance of the water was always negative; energy loss due to long-wave water back radiation was in fact greater than energy gains from the radiation associated with atmosphere and riparian vegetation.

Short-wave solar radiation was the most significant radiative component. Maximum heat flux associated with short-wave radiation ranged between $252.7 \mathrm{~W} \cdot \mathrm{m}^{-2}$ during overcast day in March and $905.4 \mathrm{~W} \cdot \mathrm{m}^{-2}$ during cloudless day in July. Dynamic changes in radiation heat flux during the study days were a result of riparian vegetation and cloud cover, so daily pattern of short-wave radiation was never a slight curve

Table 2. Average values of selected meteorological and hydrological parameters

\begin{tabular}{|l|c|c|c|c|c|}
\hline \multicolumn{1}{|c|}{ Parameter } & Units & 2013.07 .04 & 2013.09 .30 & 2014.03 .18 & 2014.05 .13 \\
\hline Solar radiation & $\mathrm{W} \cdot \mathrm{m}^{-2}$ & 150.2 & 86.5 & 39.6 & 93.4 \\
\hline Air temperature & ${ }^{\circ} \mathrm{C}$ & 20.2 & 4.4 & 7.8 & 10.5 \\
\hline Relative Humidity & $\%$ & 69.6 & 87.3 & 77.0 & 81.6 \\
\hline Wind speed & $\mathrm{m} \cdot \mathrm{s}^{-1}$ & 0.1 & 0.05 & 0.5 & 0.2 \\
\hline Water temperature & ${ }^{\circ} \mathrm{C}$ & 19.8 & 9.3 & 5.6 & 13.3 \\
\hline Streambed temperature & ${ }^{\circ} \mathrm{C}$ & 18.7 & 10.2 & 5.6 & 12.5 \\
\hline Flow rate & $\mathrm{m}^{3} \cdot \mathrm{s}^{-1}$ & 3.3 & 2.1 & 6.5 & 3.1 \\
\hline Forest cover factor & - & 0.3 & 0.25 & 0.05 & 0.25 \\
\hline
\end{tabular}


Table. 3. Absolute average heat gains and losses in diurnal energy budget of the Świder River (in $\mathrm{W} \cdot \mathrm{m}^{-2}$ )

\begin{tabular}{|l|r|r|r|r|r|r|r|r|}
\hline \multirow{2}{*}{ Day } & \multicolumn{2}{c|}{2013.07 .04} & \multicolumn{2}{c|}{2013.09 .30} & \multicolumn{2}{c|}{2014.03 .18} & \multicolumn{2}{c|}{2014.05 .13} \\
\hline \multicolumn{1}{|c|}{ Component } & $\begin{array}{c}\text { Heat } \\
\text { gains }\end{array}$ & $\begin{array}{c}\text { Heat } \\
\text { losses }\end{array}$ & $\begin{array}{c}\text { Heat } \\
\text { gains }\end{array}$ & $\begin{array}{c}\text { Heat } \\
\text { losses }\end{array}$ & $\begin{array}{c}\text { Heat } \\
\text { gains }\end{array}$ & $\begin{array}{c}\text { Heat } \\
\text { losses }\end{array}$ & $\begin{array}{c}\text { Heat } \\
\text { gains }\end{array}$ & $\begin{array}{c}\text { Heat } \\
\text { losses }\end{array}$ \\
\hline Radiation & 133.1 & -29.1 & 69.3 & -54.9 & 34.9 & -10.3 & 70.0 & -30.7 \\
\hline Evaporation/condensation & 0.0 & -2.9 & 0.0 & -1.5 & 0.0 & -0.5 & 0.0 & -1.9 \\
\hline Sensible heat & 0.6 & -0.4 & 0.2 & -1.1 & 0.7 & -0.1 & 0.1 & -0.6 \\
\hline Bed conduction & 0.1 & -10.1 & 7.9 & 0.0 & 0.6 & -1.5 & 0.0 & -9.6 \\
\hline Friction & 3.9 & - & 2.4 & - & 5.8 & - & 2.8 & - \\
\hline Total & 137.8 & -42.5 & 79.7 & -57.5 & 42.1 & -12.4 & 72.9 & -42.8 \\
\hline
\end{tabular}

Table. 4. Average percentage contributions of heat gains and losses in energy budget of the Świder River (\%)

\begin{tabular}{|l|c|c|c|c|c|c|c|c|}
\hline \multicolumn{1}{|c|}{ Day } & \multicolumn{2}{c|}{2013.07 .04} & \multicolumn{2}{c|}{2013.09 .30} & \multicolumn{2}{c|}{2014.03 .18} & \multicolumn{2}{c|}{2014.05 .13} \\
\hline \multicolumn{1}{|c|}{ Component } & $\begin{array}{c}\text { Heat } \\
\text { gains }\end{array}$ & $\begin{array}{c}\text { Heat } \\
\text { losses }\end{array}$ & $\begin{array}{c}\text { Heat } \\
\text { gains }\end{array}$ & $\begin{array}{c}\text { Heat } \\
\text { losses }\end{array}$ & $\begin{array}{c}\text { Heat } \\
\text { gains }\end{array}$ & $\begin{array}{c}\text { Heat } \\
\text { losses }\end{array}$ & $\begin{array}{c}\text { Heat } \\
\text { gains }\end{array}$ & $\begin{array}{c}\text { Heat } \\
\text { losses }\end{array}$ \\
\hline Radiation & 96.5 & 68.5 & 87.0 & 95.5 & 83.0 & 83.2 & 96.1 & 71.7 \\
\hline Evaporation/condensation & 0 & 6.9 & 0.0 & 2.5 & 0.0 & 4.3 & 0.0 & 4.4 \\
\hline Sensible heat & 0.5 & 0.9 & 0.2 & 2.0 & 1.6 & 0.1 & 0.1 & 1.5 \\
\hline Bed conduction & 0.1 & 23.7 & 9.8 & 0.0 & 1.5 & 12.4 & 0.0 & 22.4 \\
\hline Friction & 2.9 & - & 3.0 & - & 13.9 & - & 3.8 & - \\
\hline Total & 100 & 100 & 100 & 100 & 100 & 100 & 100 & 100 \\
\hline
\end{tabular}

(Fig. 2 and 3). Long-wave radiation heat fluxes changed more in seasonal terms so their diurnal cycles were more aligned. Long-wave atmospheric radiation flux, which was mainly function of cloud cover and air temperature, reached maximum value from $242.1 \mathrm{~W} \cdot \mathrm{m}^{-2}$ during autumn to $314.7 \mathrm{~W} \cdot \mathrm{m}^{-2}$ during overcast day in early spring. Long-wave riparian vegetation radiation was dependent mainly on the forest cover factor and changed with vegetative season. Maximum heat flux ranged from $17.9 \mathrm{~W} \cdot \mathrm{m}^{-2}$ in early spring to $134.3 \mathrm{~W} \cdot \mathrm{m}^{-2}$ in summer, when vegetation on the

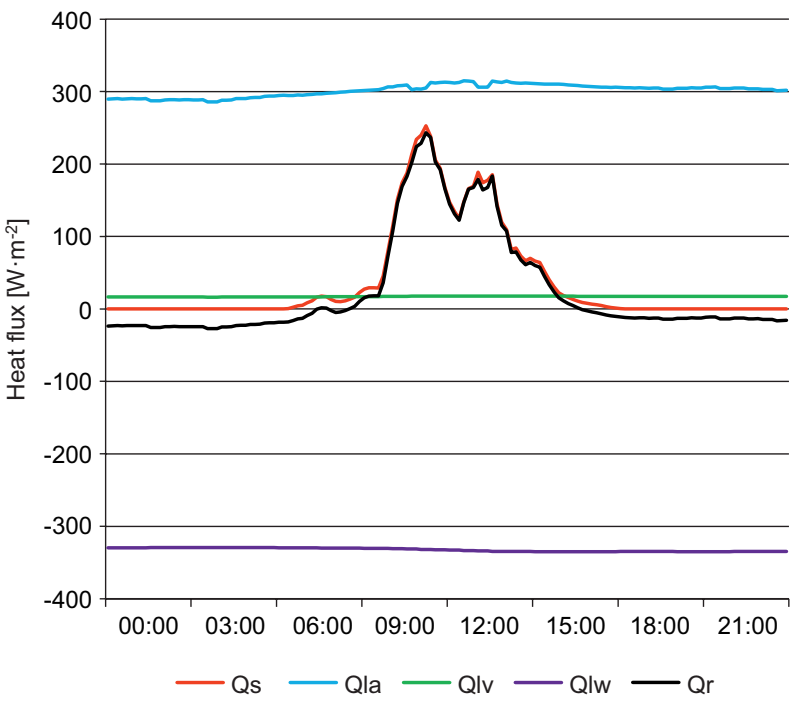

Fig. 2. Radiation components of the energy budget during early spring day - 18 March 2014 (see explanations in text) river banks was in full extent of development. Long-wave water back radiation cycle during all study days was the most aligned from long-wave radiation components due to relatively small diurnal changes in water temperature. However, heat flux associated with long-wave water radiation was quantitatively significant and peaked from $-335.0 \mathrm{~W} \cdot \mathrm{m}^{-2}$ in March to $-415.0 \mathrm{~W} \cdot \mathrm{m}^{-2}$ in July. Absolute average values of all radiative heat fluxes are detailed in Table 5.

Evaporative heat flux during the study period was responsible for the energy losses and

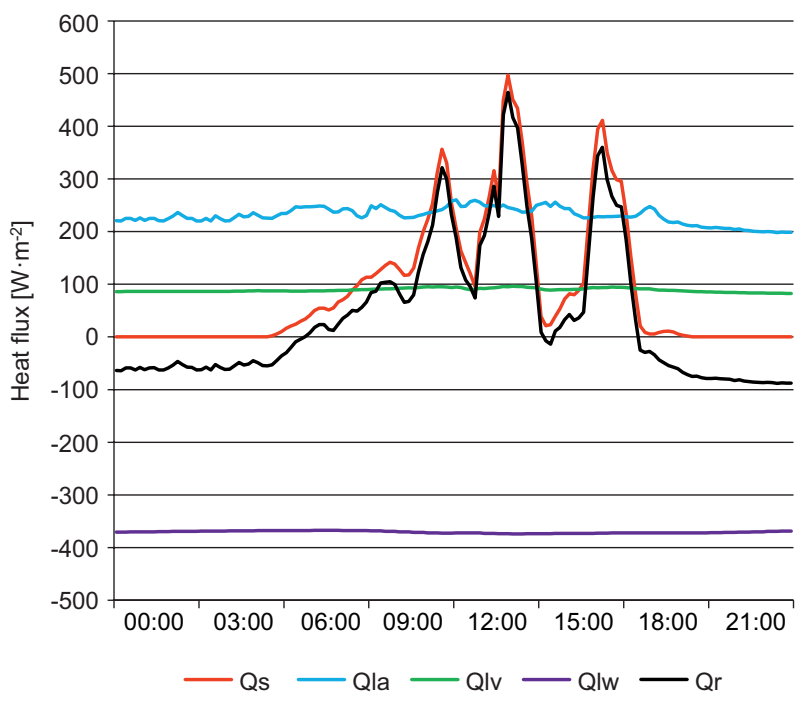

Fig. 3. Radiation components of the energy budget during late spring day - 13 May 2014 (see explanations in text) 
Table 5. Absolute average radiative heat fluxes during study days (in $\mathrm{W} \cdot \mathrm{m}^{-2}$ )

\begin{tabular}{|l|c|c|c|c|}
\hline \multicolumn{1}{|c|}{ Radiative component } & 2013.07 .04 & 2013.09 .30 & 2014.03 .18 & 2014.05 .13 \\
\hline Short-wave solar radiation & 146.8 & 84.6 & 38.4 & 90.6 \\
\hline Long-wave atmospheric radiation & 240.1 & 198.0 & 301.4 & 230.3 \\
\hline Long-wave riparian vegetation radiation & 122.6 & 81.8 & 17.1 & 89.1 \\
\hline Long-wave water back radiation & -405.4 & -350.0 & -332.3 & -370.6 \\
\hline
\end{tabular}

had clear daily cycle, dependent on meteorological conditions. The greatest energy losses occurred in the afternoon, characterised by low relative humidity, high air temperature and wind speed (Fig. 4), while minimum losses were observed usually in the early morning. Evaporative heat flux accounted on average between $2.5 \%$ and $6.9 \%$ of diurnal energy losses (Table 4) and peaked value of $-6.2 \mathrm{~W} \cdot \mathrm{m}^{-2}$ on the $4^{\text {th }}$ of July. In specific, favourable conditions there was observed heat flux associated with condensation - relative humidity exceeded $95 \%$ while water temperature was higher than the air temperature. However, condensation heat flux was very small, reaching a maximum value of $0.1 \mathrm{~W} \cdot \mathrm{m}^{-2}$, and its contribution in diurnal energy budget was therefore negligible.

Sensible heat transfer resulted in both gains and losses of the energy. Process was strictly driven by the temperature gradient between air and water, in consequence depended on the time of the day. In the morning and late afternoon there were observed energy losses, in turn, there were small gains of the energy in the afternoon as the result of the contact

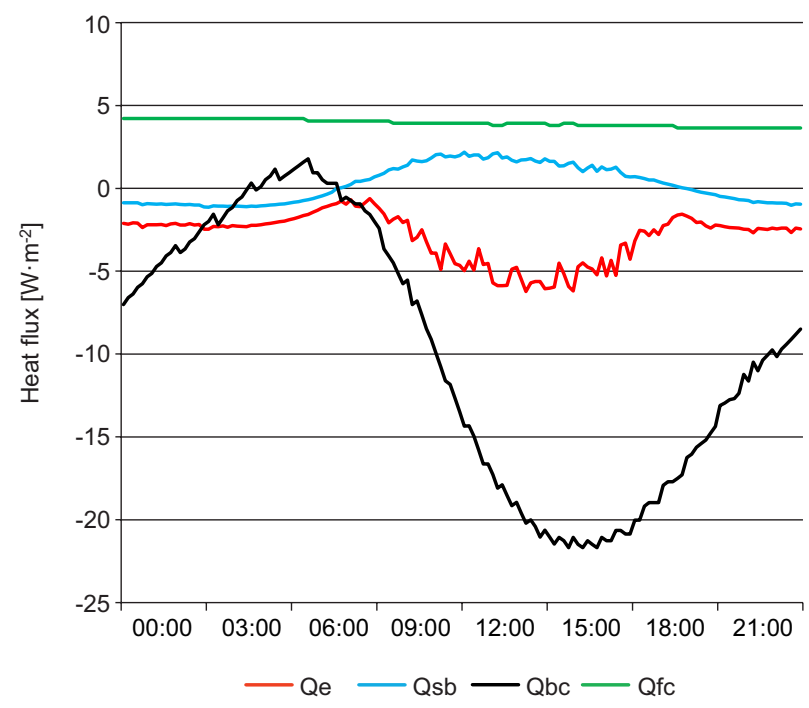

Fig. 4. Non-radiative components of the energy budget during summer day - 4 July 2013 (see explanations in text) with warmer air (Figs 4 and 5). Average contribution of sensible heat transfer in energy gains and losses ranged from $0.1 \%$ to $1.6 \%$ and from $0.1 \%$ to $2.0 \%$, respectively (Table 4 ). Maximum energy gains associated with sensible heat transfer were $2.2 \mathrm{~W} \cdot \mathrm{m}^{-2}$ while peak losses $-2.2 \mathrm{~W} \cdot \mathrm{m}^{-2}$.

Conduction between water and bed sediments showed variable direction of heat flux and amount of energy was relatively essential (Fig. 4). Average contribution of bed conduction in daily energy gains and losses ranged from $0.0 \%$ to $9.8 \%$ and from $0.0 \%$ to $23.7 \%$, respectively (Table 4 ). Heat flux associated with bed conduction peaked value of $13.1 \mathrm{~W} \cdot \mathrm{m}^{-2}$ (gains) and $-21.7 \mathrm{~W} \cdot \mathrm{m}^{-2}$ (losses).

Thermal energy generated in the process of fluid friction was a prominent component of daily energy budget during all study days (Table 4). Average contribution of friction in energy gains accounted between $2.9 \%$ and $13.9 \%$. Due to small changes in flow rate, the amount of energy gains from friction showed no significant differences during the study days (Fig. 4 and 5) but reached a maximum value of even $6.1 \mathrm{~W} \cdot \mathrm{m}^{-2}$ on the $18^{\text {th }}$ of March, when the highest flow rate was observed.

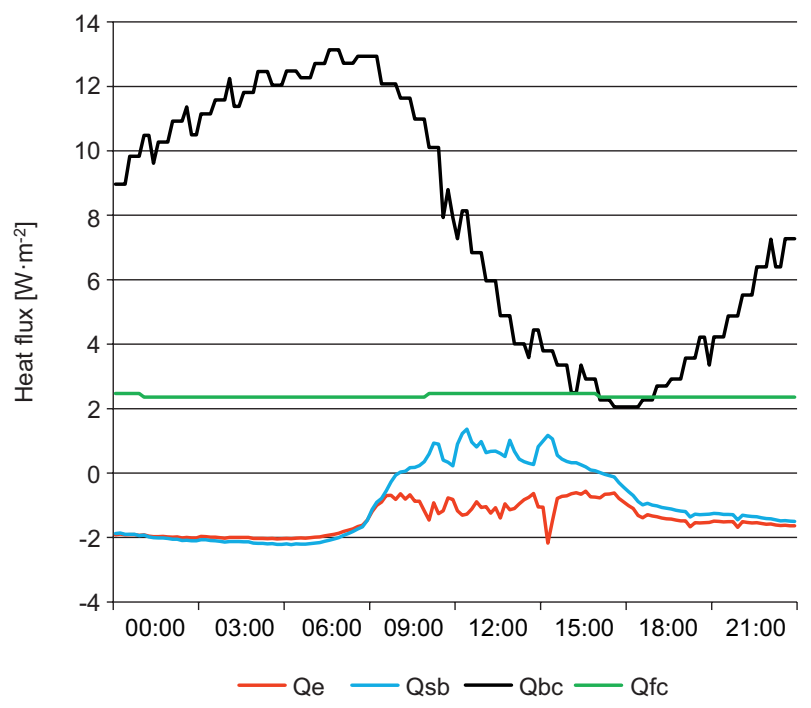

Fig. 5. Non-radiative components of the energy budget during autumn day - 30 September 2013 (see explanations in text) 


\section{Discussion and conclusion}

Despite the small number of measurements days due to technical restraints, this study seems to be valuable especially because of the total lack of data from the other lowland Polish rivers. Results indicate that the energy budget of the downstream part of the Świder River is controlled primarily by radiative heat fluxes. The average contribution of radiation in heat gains and losses during the study days was $90.7 \%$ and $79.7 \%$, respectively. The main radiative component, short-wave radiation, was a function of sunbeams angle (and consequently the time of year) and the degree of shading. Shading caused the extinction and absorption of shortwave radiation and also prevented the energy loss through long-wave radiation by water and emitted own vegetation radiation. The largest absorption and extinction of solar radiation took place in the morning and evening, when the water surface was most effectively shaded by trees and channel banks, while the smallest was in the afternoon when the sunbeams were characterised by the largest angle of incidence. Short-wave radiation flux was also strongly dependent on cloud cover, which importance shows the comparison of energy budget on the $30^{\text {th }}$ of September 2013 and $18^{\text {th }}$ of March 2014. Seemingly these days were characterised by a similar sunbeams angle, however, due to total cloud cover on the $18^{\text {th }}$ of March, the solar radiation heat flux reaching the water surface on this day was much smaller, with an average value of only $38.4 \mathrm{~W} \cdot \mathrm{m}^{-2}$ and peak of $252.7 \mathrm{~W} \cdot \mathrm{m}^{-2}$, while on the $30^{\text {th }}$ of September there was an average of $84.6 \mathrm{~W} \cdot \mathrm{m}^{-2}$, maximum $616 \mathrm{~W} \cdot \mathrm{m}^{-2}$ (despite the greater shading associated with riparian vegetation). Cloud cover, besides affecting atmospheric transmissivity and scattering of solar radiation, resulted in an increase of atmosphere emissivity; on the $18^{\text {th }}$ of March the average long-wave atmospheric radiation flux was $301.4 \mathrm{~W} \cdot \mathrm{m}^{-2}$, on the $30^{\text {th }}$ of September 30 only $198.7 \mathrm{~W} \cdot \mathrm{m}^{-2}$. Conclusions confirm findings of Evans et al. (1998), who emphasized the important role of clouds in modifying radiative heat fluxes in the case of the English River Blythe.

Non-radiative heat fluxes had significantly smaller contribution in the energy budget. During all study days evaporation was responsible on average for $4.5 \%$ of energy losses while the energy gains as a result of condensation were found only on the $18^{\text {th }}$ of March 2014 and can be considered as negligible. Marginal heat flux associated with condensation confirmed the findings of other authors (Webb and Zhang 1999). The average contribution of sensible heat transfer in energy gains and losses during study period was respectively $0.6 \%$ and $1.1 \%$. Sensible heat transfer was in consequence the least important non-advective process in the energy budget and, together with evaporation, demonstrated less participation compared to the results presented by other researchers (Webb and Zhang 1997, Evans et al. 1998, Hebert et al. 2011). One of the main reasons seems to be the presence of natural riparian vegetation, creating a local riverside microclimate. Dense vegetation reduces wind speed, diurnal variability of air temperature, and increases relative humidity (Webb and Zhang 1997, Hannah et al. 2008, Garner et al. 2014). Slower air circulation, higher vapour pressure and lower thermal gradient between the water and the air cause a consequent reduction in the intensity of evaporation and sensible heat transfer. These specific properties of the riverside climate make that the evaluation of the energy budget of small lowland rivers need to carry precise meteorological measurements in situ. This was emphasized by Hebert et al. (2011) and Benyahya et al. (2012) for measuring solar radiation and wind speed, but the author also refers to the relative humidity, which has been reaching a higher average value than in the open areas.

Average contribution of bed conduction in energy gains and losses during all study days was $2.9 \%$ and $14.6 \%$, respectively. The results confirm that bed conduction process is responsible mainly for energy losses due to generally lower temperature of bottom sediments than water temperature, especially in summer months. Moreover, heat flux associated with bed conduction is difficult to precise, quantitative evaluation, mainly due to spatial diversity of bottom sediments, and reliable results requires deployment of large number of sensors within individual river bed forms (riffles, pools) (Evans and Petts 1997). An important role of bed conduction was previously shown by Evans et al. (1998), Webb and Zhang (1999) and Hebert et al. (2011). 
The average contribution of friction in the energy budget of the downstream Świder River was $5.9 \%$ of energy gains. In consequence friction can be considered to be the most important non-radiative energy load process. It can be assumed that in winter, during periods of high flow rate, the participation of friction in the energy budget can be even greater, especially in case of small contribution of the remaining heat fluxes; this was also noted by Webb and Zhang (1999). In addition, the amount of energy will be greater on sites, characterized by higher stream gradient. The results confirm importance of fluid friction; energy generated in this process prevents water from freezing in winter (Theurer et al. 1984).

The study confirmed that the dominant contribution to the lowland river energy budget can be attributed to heat transfer, which occurred in the atmosphere-water interface $(88.3 \%)$, while the significance of heat exchanged in the streambed-water interface was far lower $(8.3 \%)$. The results are similar to those presented by Evans et al. (1998) and Hebert et al. (2011). Observed disparity is probably due to the negligence of groundwater and precipitation impact, as well as due to the use of other methods of heat flux estimation. The difference between the amount of energy gained and lost during all study days was mainly because of the fact, that heat flux are a partial reflection of the weather conditions on the preceding day. In this context measurement errors of sensors and errors resulting from the adopted methodology (solar radiation measurements and the formula determining the rate of evaporation) are also meaningful.

\section{Acknowledgements}

Author is very grateful to Ph. D. Urszula Somorowska, Associate Professor, for all support during river energy budget study. Also, author wishes to thank Katarzyna Bailey for guidance during the preparation of the English version of the text.

\section{References}

Alduchov O.A., Eskridge R.E., 1996. Improved Magnus Form Approximation of Saturation Vapor Pressure. Journal of Applied Meteorology 35: 601-609.

Allan J.D., Castillo M.M., 2007. Stream Ecology. Structure and Function of Running Waters. Springer, Dordrecht.

Armour C.L., 1991. Guidance for evaluating and recommending temperature regimes to protect fish. U.S. Fish and Wildlife Service Instream Flow Information Paper 28, Biological Report 90, Washington DC.

Benyahya L., Caissie D., Satish M.G., El-Jabi N., 2012. Longwave radiation and heat flux estimates within a small tributary in Catamaran Brook (New Brunswick, Canada). Hydrological Processes 26: 475-484. DOI 10.1002/hyp.8141.

Bowen I.S., 1926. The ratio of heat losses by conduction and by evaporation from any water surface. Physics Review 27: 779-787.

Boyd M., Kasper B., 2003. Analytical methods for dynamic open channel heat and mass transfer: methodology for the Heat Source Model Version 7.0. Watershed Sciences Inc., Portland, OR, USA.

Buck A.L., 1981. New Equations for Computing Vapor Pressure and Enhancement Factor. Journal of Applied Meteorology 20: 1527-1532.

Deas M.L., Lowney C.L., 2000. Water temperature Modeling Review. California Water Modeling Forum, Central Valley, California.

Evans E.C., Petts G.E., 1997. Hyporheic temperature patterns within riffles. Hydrological Sciences-Journal-des Sciences Hydrologiques 42: 199-213.

Evans E.C., McGregor G.R., Petts G.E., 1998. River energy budgets with special reference to river bed processes. Hydrological Processes 12: 575-595.

Garner G., Malcolm I.A., Sadler J.P., Millar C.P., Hannah D.M., 2014. Inter-annual variability in the effects of riparian woodland on micro-climate, energy exchanges and water temperature of an upland Scottish stream. Hydrological Processes. DOI 10.1002/hyp.10223.

Hannah D.M., Malcolm I.A., Soulsby C., Youngson A.F., 2008. A comparison of forest and moorland stream microclimate, heat exchanges and thermal dynamics. Hydrological Processes 22: 919-940. DOI 10.1002/hyp.7003.

Hebert C., Caissie D., Satish M.G., El-Jabi N., 2011. Study of stream temperature dynamics and corresponding heat fluxes within Miramichi River catchments (New Brunswick, Canada). Hydrological Processes 25: 2439-2455. DOI: 10.1002/hyp.8021.

Hondzo M., Stefan H.G., 1994. River bed heat conduction prediction. Water Resources Research 30: 1503-1513.

Malcolm I., Soulsby C., Hannah D.M., Bacon P.J., Youngson A.F., Tetzlaff D., 2008. The influence of riparian woodland on stream temperatures: implications for the performance of juvenile salmonids. Hydrological Processes 22: 968-979. DOI: 10.1002/hyp.6996.

Morin G., Couillard D., 1990. Predicting river temperatures with a hydrological model. In: Cheremisinoff N.P. (eds), Encyclopedia of Fluid Mechanic, Surface and Groundwater Flow Phenomena. Gulf Publishing Company, Hudson, Texas, USA: 171-209.

Theurer F.D., Voos K.A., Miller W.J., 1984. Instream Water Temperature Model. Instream Flow Information Paper 16, U.S. Fish and Wildlife Service. 
Webb B.W., Zhang Y., 1997. Spatial and seasonal variability in the components of the river heat budget. Hydrological Processes 11: 79-101.

Webb B.W., Zhang Y., 1999. Water temperatures and heat budgets in Dorset chalk water courses. Hydrological Processes 13: 309-321.

Westhoff M.C., Savenije H.H.G., Luxemburg W.M.J., Stelling G.S., Van de Giesen N.C., Selker J.S., Pfister L., Uhlen- brook S., 2007. A distributed stream temperature model using high resolution temperature observations. Hydrological Earth System Sciences 11: 1469-1480. DOI 10.5194/ hess-11-1469-2007.

Xin Z., Kinouchi T., 2013. Analysis of stream temperature and heat budget in an urban river under strong anthropogenic influences. Journal of Hydrology 489: 16-25. DOI 10.1016/j.jhydrol.2013.02.048. 